\title{
Microenvironmental stimuli for proliferation of functional islet $\beta$-cells
}

\author{
Hanan Alismail ${ }^{1,3}$ and Sha Jin $^{2^{*}}$
}

\begin{abstract}
Diabetes is characterized by high blood glucose level due to either autoimmune destruction of islet $\beta$-cells or insufficient insulin secretion or glucose non-responsive production of insulin by $\beta$-cells. It is highly desired to replace biological functional $\beta$-cells for the treatment of diabetes. Unfortunately, $\beta$-cells proliferate with an extremely low rate. This cellular property hinders cell-based therapy for clinical application. Many attempts have been made to develop techniques that allow production of large quantities of clinically relevant islet $\beta$-cells in vitro. A line of studies evidently demonstrate that $\beta$-cells can proliferate under certain circumstances, giving the hopes for generating and expanding these cells in vitro and transplanting them to the recipient. In this review, we discuss the requirements of microenvironmental stimuli that stimulate $\beta$-cell proliferation in cell cultures. We highlight advanced approaches for augmentation of $\beta$-cell expansion that have recently emerged in this field. Furthermore, knowing the signaling pathways and molecular mechanisms would enable manipulating cell proliferation and optimizing its insulin secretory function. Thus, signaling pathways involved in the enhancement of cell proliferation are discussed as well.
\end{abstract}

Keywords: Islets of Langerhans, $\beta$-cell proliferation, Diabetes, Insulin, Mitogen

\section{Introduction}

Pancreatic $\beta$-cell is considered as one of the most important cell types in the islet of Langerhans in pancreas. It is responsible to insulin production in response to blood glucose level. The result of either insulin deficiency or sugar level irregulated insulin secretion is diabetes mellitus [1]. Type I and II diabetes are two common types of this disease. Type I diabetes (T1D) results from the autoimmune destruction of $\beta$-cells, making the body incapable of maintaining normoglycemia in these patients. In type II diabetes (T2D), either the body does not produce enough insulin due to a decrease in functional $\beta$-cell mass, or the insulin secretion does not correlate to glucose levels in the blood. Diabetes induces other diseases, including heart disease and stroke, high blood pressure, kidney disease, and blindness. The Centers for Disease Control and Prevention estimated that 25.8 million people of the U.S. population are having this disease in 2011 [2]. World Health Organization suggested that the global number of diabetic patients would reach 300 million and being the

\footnotetext{
* Correspondence: sjin@binghamton.edu

${ }^{2}$ Department of Bioengineering, Thomas J. Watson School of Engineering and Applied Sciences, State University of New York in Binghamton, Binghamton, NY 13902, USA

Full list of author information is available at the end of the article
}

$7^{\text {th }}$ leading cause of death by the year 2030 [3]. Current treatment for T1D includes insulin supplement by either tablet, injection, or organ transplantation [4]. However, organ transplantation causes complications regardless the scarcity of donors and histocompatibility matching issues [5]. On the other hand, medical treatment for T2D is fairly limited. Driven by the urgent need to treat patients suffering from diabetes, intensive research efforts have been made to create biologically functional islet tissues that can be used to replace diseased islets and to regenerate a healthy tissue for the realization of cell-based therapy.

One of the main challenges remains in adult pancreatic $\beta$-cell therapy is the extremely low proliferation rate which is approximately $0.1 \sim 0.3 \%$ a day in aged adult animal and minimum replication capacity in adult human [6]. Fortunately, $\beta$-cell mass expansion can occur in early postnatal life, pregnancy, and animal models which were genetically modulated [7-9]. Thus, it is important to fully understand the molecular mechanisms that allow enhancing the pancreatic $\beta$-cell proliferation, so that cells can be cultured in an environment suitable for in vitro production. Inducers of $\beta$-cell proliferation can be classified to extrinsic and intrinsic path. Extrinsic mitogens include: glucose, amino acids, insulin like growth factors, prolactin 
(PRL), placental lactogen (PL), glucagon-like peptide-1 (GLP-1), growth hormone, hepatocyte growth factor (HGF), epidermal growth factors, transforming growth factor (TGF), and extracellular matrix (ECM) [10-12]. The intrinsic factors include cyclins, cyclin dependent kinases, and cyclin dependent kinas inhibitors [13]. This review focuses on the most important extrinsic mitogens and signaling pathways that are involved in the process of $\beta$-cell proliferation. The review also overviews advanced approaches and applications in the field of islet $\beta$-cell expansion and biological functionalization.

\section{Native $\boldsymbol{\beta}$-cells and their surroundings}

Islets of Langerhans are comprised of five types of cells: $\alpha, \beta, \delta, \varepsilon$, and PP-cells. These cells work as a micro organ to maintain glucose homeostasis. $\beta$-cell is the most abundant and important cell in islets, which senses the circulating glucose level in the blood and responses glucose level by secreting insulin accordingly [14]. $\beta$-cell receives regulation signals from a pancreatic and nonpancreatic environment that promote its function and proliferation [14]. As diagramed in Figure 1, first of all, a dense vascular network exists within the islets facilitates efficient oxygen and insulin secretion. $\beta$-cells cross interact with the endothelial cells of the capillary network through the vascular basement membrane. $\beta$-cells secret vascular endothelial growth factor to promote the vascular development, whereas the endothelial cells produce a basement membrane rich with laminin to support the insulin gene expression and secretion from $\beta$-cells and further $\beta$-cells proliferation [15]. Second, cell-cell contacts between $\beta$-cells, through several transmembrane receptors, have a great impact on insulin gene expression and

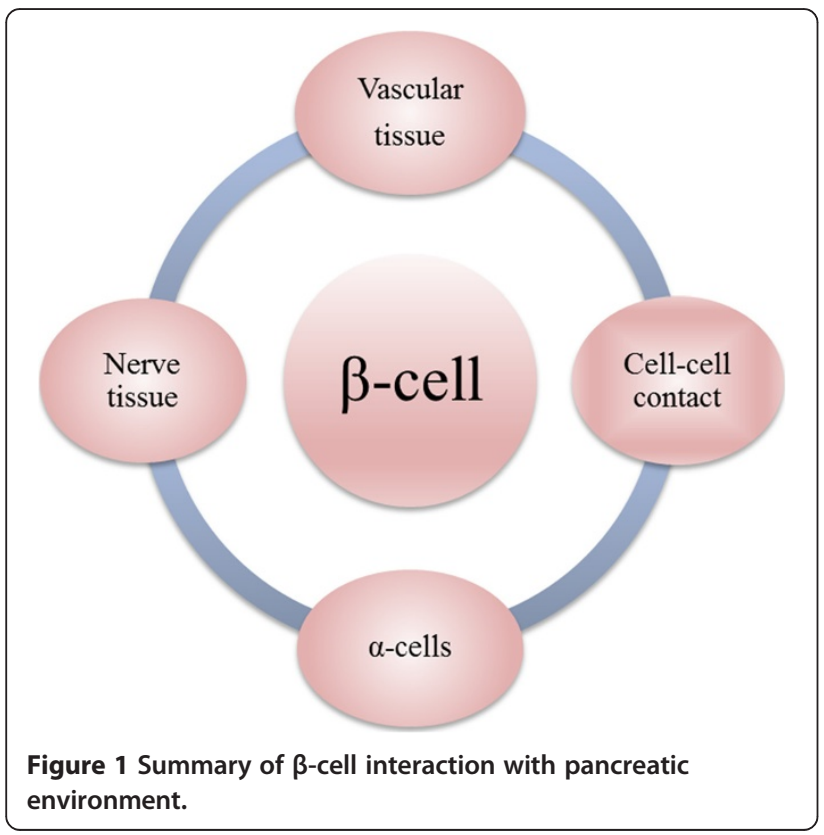

glucose stimulated insulin secretion (GSIS) [16]. Third, $\beta$ cells interact with $\alpha$-cells in reciprocal secretion to maintain glucose homeostasis [17]. Fourth, islets are rich with neurons from sympathetic and parasympathetic nervous system. Interaction between $\beta$-cells and parasympathetic neurons activates specific receptors to induce GSIS, whereas sympathetic neurons inhibit insulin secretion as a part of the physiological glucose homeostasis [18] (Figure 1). Moreover, $\beta$-cells receive signals from non-pancreatic tissues such as: liver, bone, fat, and gut, endocrine cells of the intestine [14]. These cells secrete integrins which bind to a G-coupled receptor on the $\beta$-cell surface to stimulate the insulin secretion and $\beta$-cell proliferation [19]. In the process of islet isolation all of these vascular and nerve connections are destroyed by enzymatic digestion of the pancreas and islet purification through a density centrifugation, which could be the major cause of malfunction of $\beta$-cell and low survival after isolation procedures [20,21]. Motivated by the need of creating an optimal niche for $\beta$-cell expansion, biologically functional materials and signaling molecules for creating a niche that can support cell expansion both in vitro and after transplantation have been explored. The details are discussed as follows.

\section{Extrinsic mitogens}

\section{Glucose}

Glucose is one of the important regulators in $\beta$-cell proliferation, since the primary function of $\beta$-cell is to lower blood glucose level by insulin secretion. Evidence indicating the role of glucose in the $\beta$-cell proliferation has been reported in several studies both in in vitro and in vivo. For example, glucose is a key nutrient for cell growth in fetal and neonatal $\beta$-cell [22], insulinoma cell lines [23], primary islets [24], and human $\beta$-cells [25]. In vivo glucose infusion subjected to diabetic mice and rats result in increase in $\beta$-cell mass ultimately [26-28].

The signaling pathways which are correlated glucose with $\beta$-cell quantity, proliferation, and apoptosis have been extensively investigated. Several pathways revealed to be involved are: (1) insulin autocrine effect, (2) calcium signaling, and (3) TSC2/mTOR inhibitory signaling pathway [29] (Figure 2). In vitro studies demonstrated that glucose induces intracellular signaling molecules such as phosphatidylinositol 3-kinase (PI3K), protein kinase $B(\mathrm{PKB})$, glycogen synthase kinase-3 (GSK-3), extracellular signal-regulated kinase (ERK) $1 / 2$, and mammalian target of rapamycin (mTOR), as well as insulin receptor substrate 2 (IRS2) [30,31]. Activation of insulin receptor leads to the activation of the Akt signaling pathway which is considered to be one of the main pathways of $\beta$-cell proliferation [32,33]. Moreover, this activation is down regulated by mTOR signaling triggered by an increase in ATP production and leads to the subsequent 


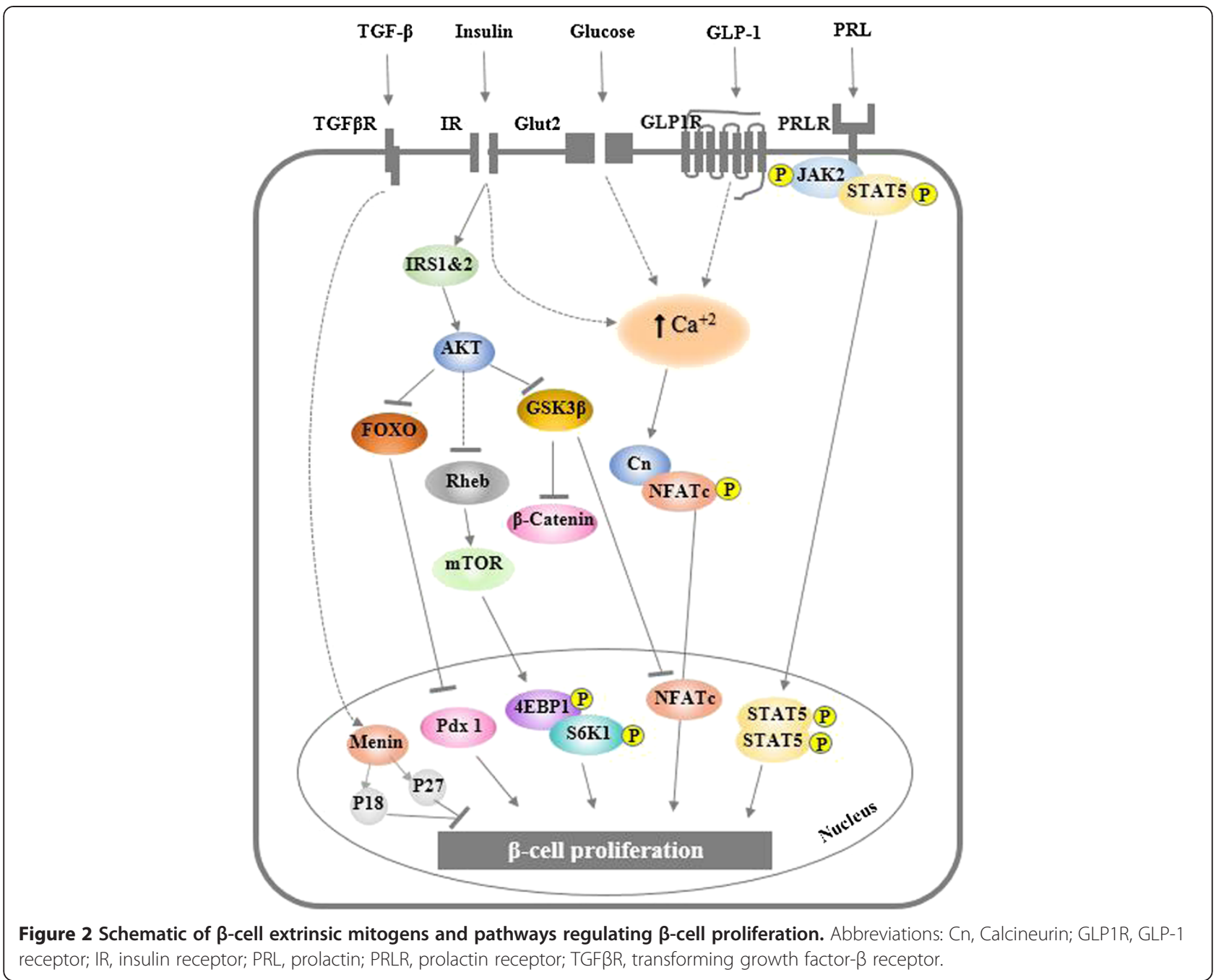

inactivation of AMP kinase (AMPK) [15]. Finally, the calcium signaling pathway has also a significant remark through cornering, the only calcium regulated phosphates. Study on an investigation of the importance of the pathway has been conducted by deleting the calcineurin regulatory subunit, calcineurin b1 (Cnb1). This study results in reduced $\beta$-cell proliferation and developing age related diabetes. The correction for this defect was made by expressing the active nuclear factor of activated $\mathrm{T}$ cell cytoplasmic 1 (NFATc1), which is a downstream transcription factor in this pathway [34]. Moreover, activation of transcription factors cAMP response elementbinding protein (CREB) and serum response factor (SRF) can improve $\beta$-cell growth rate through glucose/calcium pathway $[35,36]$.

Although the moderate glucose elevation causes an increase in $\beta$-cells growth and survival, prolonged exposure to high concentration of glucose is the main cause of $\beta$ cell deterioration and apoptosis. This condition is called glucotoxicity, which is caused by several of mechanisms that are not fully understood [37,38]. A line of studies found a number of transcriptional regulators that are sensitive to the level and duration of glucose and insulin gene expression such as MafA, NFAT [39,40], somatostatin transcription factor-1 (STF-1), pancreatic and duodenal homeobox 1 ( $\mathrm{Pdx}-1)$, and the insulin control element (ICE) [41]. It was shown that these proteins are expressed in the presence of $0.8 \mathrm{mM}$ glucose and in a prolonged exposure to a high level of $11.1 \mathrm{mM}$ glucose [37]. In addition, MafA protein level is able to restore insulin expression in $\beta$-cell lines along with the present of prolonged high glucose level [42]. High glucose concentrations have also shown to inactivate AMP protein kinase (AMPK) in the $\beta$-cell and result in impaired GSIS due to lipid accumulation which leads to the deterioration of $\beta$-cell function [43-45].

Another set of studies revealed that glucose toxicity may lead to oxidative stress in organelles such as in the endoplasmic reticulum and mitochondria [46,47]. Increase in oxidative stress causes a reduction binding of $\operatorname{Pdx} 1$ and 
MafA to insulin gene in pancreas, which in turn results in defective insulin gene expression and hormone secretion $[42,48]$. It is clear that the reactive oxygen species (ROS) activate stress-induced pathways, including nuclear factor $\mathrm{kB}(\mathrm{NF}-\mathrm{kB})$, and $\mathrm{c}$-Jun $\mathrm{N}$ terminal kinase (JNK) pathways $[49,50]$. The subsequent JNK signaling event leads to the inactivation of IRS-1 by its phosphorylation on Ser307 [51]. A recent study suggested that hypoxia is another reason causing malfunction of $\beta$-cells. Expression of transcription factor hypoxia-inducible factor (HIF) plays an adverse role in $\beta$-cell function [52]. Under the exposure to a high glucose level, an alteration in the profile of $\beta$-cell gene expression occurs, including a switch from aerobic to anaerobic glycolysis that leads to impaired GSIS and glucose intolerance. This was investigated through the deletion of the regulatory protein von Hippel-Lindau (VHL) protein for controlling the degradation of HIF which reduces the cellular oxygenation level and causes hypoxia. VHL/HIF oxygen-sensing mechanisms play a critical role in glucose homeostasis through decreasing islet oxygenation level and negatively impact $\beta$-cell function [53,54].

Furthermore, chronic hyperglycemia leads to excessive accumulation of $\mathrm{Ca}^{2+}$ in the cytosol which is a proapoptotic signal that induces $\beta$-cell dysfunction and destruction [55]. Other potent apoptosis pathways were shown to be related to interleukin-1 $\beta$ which inhibits $\beta$-cell function and promotes Fas-triggered apoptosis in part by activating the transcription factor NF- $\mathrm{kB}$ during the autoimmune process of T1D pathogenesis [56]. However, knowledge of the signaling pathway involved in chronic hyperglycemia remains elusive. In particularly, the targets and the downstream effects of glucotoxicity have not been completely elucidated.

\section{Growth factors and signaling pathways Insulin growth factor (IGF)}

Expressions of insulin growth factor I (IGF-I) and II (IGF-II) and their receptor (IGFR) were found in different stages of pancreatic development. In fact, their expressions act as signal for stimulating $\beta$-cell proliferation [57]. IGF-I and IGF-II are able to enhance $\beta$-cell proliferation in rat islets and insulinoma cell lines in vitro [58]. Interestingly, the over-expression of IGF-I results in enhanced proliferation of $\beta$-cells in transgenic mice but not the size of islets, while the over-expression of IGF-II leads to abnormal islet morphology with enlarged irregular shape $[59,60]$.

Studies also demonstrated that insulin receptor (IR) is a stimulator for $\beta$-cell proliferation [61], where the Akt and MAPK signaling pathways are involved [62]. Reduction in the IR by up to $80 \%$ in mouse $\beta$-cells MIN6 leaded to reduction of growth rate, suggesting that insulin plays a crucial role as a growth factor for this insulinoma cell line [63]. In addition, the effect of IR substrate 1 and 2 (IRS1 \&
2) has also been explored as they are modulators in the insulin/IGF signaling cascade as indicated in Figure 2. Heterozygous mutation in IRS1/IR in mice showed approximately 400-fold increase in circulating insulin in parallel to severe insulin resistance with striking hyperplasia in the $\beta$-cell mass by 40-50-fold [64]. In contrast, animal models deficient in IRS-2 showed abnormalities such as low proliferation, low Pdx-1 expression, small islet size, and increase in apoptosis [65]. Moreover, IRS2 over-expression is associated with glucose stimulation in insulinoma cells. It exhibits a synergistic increment in $\beta$-cell proliferation in glucose/IGF-1 induced manner in vitro [66]. Another study reported that IRS-2 controls other growth promoting mutagens such as exendin4 , which protects $\beta$-cells from human islet amyloid polypeptide-induced cell damage $[67,68]$. All of these studies suggested that the downstream signaling of insulin and IGF receptors are essential for maintaining $\beta$-cell mass and proliferation.

\section{Akt/PKB signaling pathway}

Akt is also known as protein kinase $\mathrm{B}(\mathrm{PKB})$, is proposed to be a crucial modulator of IRS-2-mediated signal in $\beta$-cells (Figure 2). Deficiency in AKT2 has shown a negative impact on $\beta$-cell proliferation, which provides an evidence of its importance in the signaling cascade [12]. On the contrary, AKT2 over expression induced $\beta$-cell proliferation via enhancing resistance to apoptosis and improving insulin secretion [32,33]. Some downstream targets such as forkhead transcription factor 1 (FoxO1), glycogen synthase kinase 3 beta (GSK3 $\beta$ ), and the mammalian target of rapamycin (mTOR) are down-regulated by the Akt signaling pathway and Akt functions have been described elsewhere [69-71] (Figure 2).

Pdx-1, also known as insulin promoter factor 1 (IPF1), has been investigated as an ultimate transcription factor of Akt signaling, result of its phosphorylation and nuclear inclusion plays an important role in $\beta$-cells proliferation and function [72]. However, it is still unknown how Pdx-1 regulates $\beta$-cell proliferation. In addition, $\mathrm{Pdx}-1$ can restore $\beta$-cells function in IRS2 knocked out mice, suggesting that the dysregulation of $\mathrm{Pdx}-1$ by IRS2 is directly related to the development of T2D [73].

There are multiple evidences for the inversely correlation between the forkhead transcription factor FoxO1 and the Pdx-1 expression. A group of studies showed several mechanisms in which FoxO1 can antagonize Pdx-1. FoxO1 suppression can be done through the competition binding of forkhead box protein A2 (FoxA2) protein to $\mathrm{Pdx}-1$ promoter region and restoring $\mathrm{Pdx}-1$ expression level [74]. This was further affirmed by the expression of Pdx-1 in $\beta$-cells which contain cytoplasmic FoxO1 but not nuclear FoxO1 [74]. A recent study also confirmed that FoxO1 inhibits $\beta$-cell neogenesis but it is required for the 
maintenance of insulin secretion under metabolic stress [75]. In addition, FoxO1 can lead to a nuclear exclusion of $\mathrm{Pdx}-1$ in oxidative stressed $\beta$-cell as a suppression mechanism [76]. However, it is unclear the type of molecules that are stimulated by $\mathrm{Pdx}-1$ and the mechanism of these molecules correlating with $\mathrm{Pdx}-1$ to induce $\beta$-cell proliferation.

\section{Prolactin, placental lactogen, and HGF}

Several other growth factors, such as PRL and PL, can also enhance $\beta$-cell proliferation rate both in vitro and in vivo. Prolactin as well as PL are highly expressed during pregnancy and showed to be involved in increasing $\beta$-cells mass [77]. Injection of PRL or PL leads to higher $\beta$-cell growth in experimental rodent [78]. Moreover, transgenic mice over-expressing PL demonstrated a higher $\beta$-cell growth rate associated with hyperinsulinemia [78]. In contrast, mice lacking PRL receptor reduce $\beta$-cell mass [79]. The PRL receptor belongs to the cytokine receptor family that is involved in the JAK/STAT signaling pathway [80]. Thus, binding of PL and PRL molecules to PRL receptor triggers $\beta$-cells proliferation through signaling pathway JAK2/STAT5 (Table 1).

HGF is a mesenchyme derived growth factor involved in proliferation, migration, and differentiation of several types of tissues [81]. Deletion of HGF demonstrated glucose intolerance and impaired GSIS. A protective effect against apoptosis and increase of proliferation was exhibited in induced dysfunction mice injected with exogenous HGF gene [82]. HGF binds to c-Met receptor and activates MAPK and PI3K/Akt pathways which are responsible for $\beta$-cell proliferation [83]. Hence, HGF seems to be an attractive potential target for therapy.

\section{Transforming growth factor-beta (TGF- $\beta$ )}

Transforming growth factor (TGF) family is an important regulator in the pancreas development and function. It has two classes of polypeptide growth factors, TGF- $\alpha$ and TGF- $\beta$. They have been implicated in the pathogenesis of cancer, autoimmune disease, and diabetes. Several studies have reported that the impaired TGF level can lead to the

\begin{tabular}{|c|c|c|c|c|c|c|}
\hline $\begin{array}{l}\text { Extrinsic } \\
\text { factors }\end{array}$ & MAPK & Akt & $\begin{array}{c}\mathrm{Ca}^{+2} \\
\text { signaling }\end{array}$ & Jak/Stat & Smad & $\beta$-catenin \\
\hline Glucose & $\sqrt{ }$ & & $\sqrt{ }$ & & & \\
\hline Insulin/IGF-1 & & $\sqrt{ }$ & $\sqrt{ }$ & & & \\
\hline PRL/PL & & & & $\sqrt{ }$ & & \\
\hline HGF & $\sqrt{ }$ & $\sqrt{ }$ & $\sqrt{ }$ & & & \\
\hline TGF & & & & & $\sqrt{ }$ & \\
\hline GLP-1/GIP & $\sqrt{ }$ & $\sqrt{ }$ & $\sqrt{ }$ & & & $\sqrt{ }$ \\
\hline
\end{tabular}

onset of both T1D and T2D [84]. Impaired TGF- $\beta$ is related to the progression of T1D in non-obese diabetic (NOD) mice. The cause of diabetes in these mice was autoimmune destruction of islets resulting insulin deficiency [85]. An adenoviral expression vector encoding TGF was transected to the NOD mouse islet cells. The experimental result suggested a protection to the NOD mouse islet cells from apoptosis and immune distraction and delay in diabetes occurrence for 22 days compared to the only 7 days vector transfected control [86]. Microarray on isolated intact human islets incubated in low and/or high glucose revealed a highly regulated TGF signaling in the human islets. This suggests that TGF is involved in the glucose metabolism and $\beta$-cell function as well $[87,88]$.

\section{Incretins}

Incretins are a group of hormones that lead to an increase in the amount of insulin released from the $\beta$-cells. GLP-1 and glucose-dependent insulinotropic polypeptide (GIP) are the two types of incretin hormones that have been well investigated. They are secreted from the intestine upon glucose ingestion to stimulate insulin secretion. These two hormones have shown to be involved in increasing $\beta$-cell proliferation and decreasing cell apoptosis [89]. GLP-1 infusion into glucose-intolerance rats caused an increase in the $\beta$-cell mass. Likewise, an increase in the $\beta$-cell size and neogenesis was observed in mice treated with GLP-1. Moreover, GLP-1 has an anti-apoptotic effect in freshly isolated human islets [90]. Buteau and his co-workers found that GLP-1 enhances the binding of NF-kB transcription factor to two anti-apoptotic genes: inhibitor of apoptosis protein-2 and $\mathrm{Bcl}-2$, resulting in augmentation of the expression of the anti-apoptotic proteins [7]. Therefore, GLP-1 has been approved by the FDA for being used for T2D treatment [91]. GIP has also shown to be a synergistic mitogen inducer with glucose and a pleiotropic growth factor for insulin-producing on INS-1 $\beta$-cells [92]. Indeed, GIP is strictly glucose dependent and it does not show any effect during a low blood glucose level. Thus, GIP seems to act as a blood glucose stabilizer with inverse glucose-dependent effect on pancreatic insulin [93]. In addition, the binding of GIP-1 to its G-protein couple receptor (GLP1R) activates downstream targets including cAMP and PKA, intracellular calcium, and Pdx-1, leading to $\mathrm{Pdx}-1$ expression [94-96] (Figure 2). For instance, mouse islet $\beta$-cell treated with GLP1R can activate PI3K/ Akt signal pathway and trigger a significant increase in IRS2 [97]. On the contrary, inhibition of both c-SRC and EGFR suppresses GLP1R-mediated PI3K pathway in INS-1 cells [98]. Recently, GLP-1 was found to be able to induce $\beta$-cell proliferation by increasing the $\beta$-catenin nuclear content and increasing cyclic D1 expression [99]. Table 1 summarizes the extrinsic factors and the downstream signaling pathways involved in $\beta$-cell proliferation. 


\section{Extracellular matrix}

Adult human islets are surrounded by an incomplete capsule constituted from a single layer of fibroblasts and collagen fibers. Additional matrix protein is attached to this capsule and known as peri-insular basement membrane. Mechanical and chemical signaling interactions between cells and ECM are known to regulate several philological aspects including: survival [100], proliferation [101], and insulin secretion in islets [102]. In living tissue, cells synthesize ECM components and deposit them to form a niche. A niche not only affects the tissue composition and mechanical properties, but also determines cellular fate. As aforementioned that islet $\beta$-cell can rarely proliferate in vitro. Thus, many attempts have been made to find out niches required for $\beta$-cell expansion. In a recently study, human islet cells were cultured in two ECM environments: rat ECM (804G) and bovine corneal endothelial ECM (BCEC) in the presence of GLP-1 analogue, liraglutide. It was observed that there is approximately $0.082 \pm$ $0.034 \%$ proliferation of islet $\beta$-cells in a liraglutide treated/ BCEC culture condition. The result indicates that adult human $\beta$-cell proliferation can occur in vitro but remains an extremely rare event within an environment of certain ECM and signaling molecule [103]. In another study, fully differentiated human adult insulin-producing $\beta$-cell was unable to proliferate in vitro regardless of whether or not the presence of human growth hormone (hGH) and the GLP-1 analogue liraglutide. However, hGH and GLP-1 enhanced rat $\beta$-cell proliferation [104].

Since an interaction of ECM with integrins triggers an intracellular signaling cascade and modulates the level of gene expressions that control cell behavior [105], effect of integrin on $\beta$-cell proliferation has also been explored. Studies suggested that adult human islets are expressing special types of integrins including $\alpha 3, \alpha 5, \alpha v, \alpha 6, \beta 1, \beta 3$ and $\beta 5$ [96]. Laminin-5 interacting with $\alpha 6 \beta 1$ integrin allows rat $\beta$-cell proliferation [106]. Among ligands for the $\alpha 3 \beta 1$ integrin, including fibronectin, laminin, collagen I, and collagen IV, only collagen I and IV promote rat INS-1 cell viability and proliferation [107]. Collagen type I, IV, and laminin can increase survival rate of islets after isolation procedures [108]. Nikolova and his co-workers identified laminins as endothelial signals for promoting insulin secretion of $\beta$-cells, and this augmentation relies on the interaction between $\beta 1$ integrin and the laminins [109].

\section{Tissue engineering approaches}

As mentioned previously, there is a considerable interest to understand the most important regulators and the mechanism that can stimulate the pancreatic islet growth in vitro. Tissue engineering approaches have been explored by culturing cells with highly porous scaffold biomaterials to generate a three dimensional (3D) environment for improving the islet growth and survival, as well as normal insulin secretion (Figure 3). A line of studies demonstrated that poly(ethylene glycol) (PEG) hydrogel scaffold can mimic cell-cell communication microenvironment required for insulin-secreting $\beta$-cells [110-112]. Bernard and his coworkers developed a PEG hydrogel-based microwell cell culture system using photolithography technique [113]. Mouse $\beta$-cells formed aggregates in PEG hydrogels and demonstrated more than $90 \%$ cellular viability in a week long culture. Furthermore, aggregated cells showed considerable increase in insulin secretion compared with single cell culture condition [113]. This study indicates that cell-cell adherent junction is one of the paramount factors required for the function of insulin-secreting $\beta$ cell. The importance of cell-cell adherent junction for $\beta$-cell survival and function is also evidently verified by

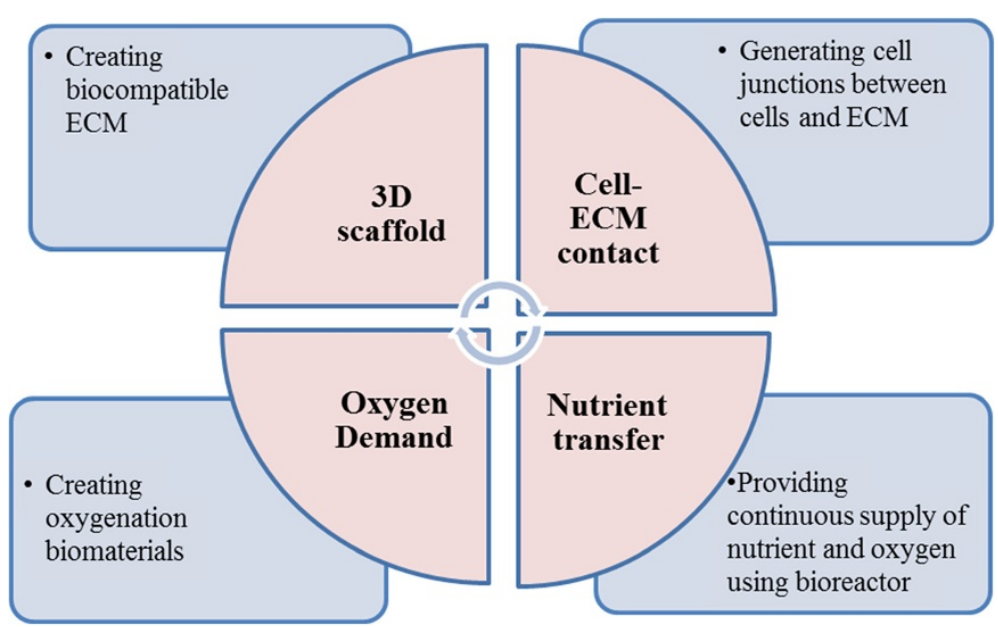

Figure 3 Tissue engineering approaches for enhancing pancreatic islet growth in vitro. 
Kelly group [114]. PEG hydrogel was fabricated to contain collagen type I, collagen type IV, fibrinogen, fibronectin, laminin, and vitronectin, and then used to encapsulate $\beta$-cells. $\beta$-cell survival was significantly improved in ECMcontaining PEG hydrogels compared with in gels without ECM over ten days. Insulin secretion was also enhanced in cells cultured in ECM-containing hydrogels [115]. The PEG/ECM-based scaffolds indeed contribute to the reestablishment of the islets-ECM interaction. Hiscox group developed a device that allows islets to be cultured in between two layers of prevascularized collagen gels. The islets exhibited a higher level of viability and functionality compared to the free islets control [116].

In another engineering approach, encapsulation of islet cells in a 3D scaffold provides protection against the immune cells and its antibodies. However, the diffusion of low molecular weight cytokines through the hydrogels remains to be challenge. To overcome this issue, scaffold surface can be fabricated by coating of PEG-hydrogel with diffusible pro-inflammatory cytokines interleukin (IL)-1 $\beta$ receptor. This modification enabled maintenance of the viability of encapsulated islet cells and function as a glucose-stimulated insulin secretion after the exposure of different cytokines [117]. Another strategy to make better $3 \mathrm{D}$ scaffold is to inhibit TNF receptor 1 by scaffolding PEG-diacrylate hydrogels coated with TNF receptor 1 . As a result, this modified hydrogel not only preserved islet insulin content, but also reduced mRNA of inducible nitric oxide synthase and IL- 6 in pancreases in experimental animals [118]. Nevertheless, impaired oxygen diffusion within a 3D scaffold hinders the wide use of scaffold for islet cell expansion. In particular, normoxia or higher oxygen tension promotes islet $\beta$-cell development from progenitor cells and increases $\beta$-cell viability [119-121], as $\beta$-cells consume large amounts of oxygen during insulin secretion [122]. Studies have shown that islet-like cell aggregates may suffer from hypoxia proportion to the radial distance inward leading to the cell necrosis and apoptosis as well as activation of the anaerobic metabolism [123]. This issue may be overcome by culturing the cell aggregates in an oxygenated system [124]. Recently, an oxygenator made from polydimethylsiloxane (PDMS)/calcium peroxide enhanced the mouse $\beta$-cell proliferation and insulin secretion for three weeks under hypoxic culture conditions [120]. The oxygenating strategy is practically promising because islet cells are usually sensitive to chemical compounds such as catalyst or hydrogen peroxide. Alternatively, mouse $\beta$-cells were cultured in suspension in a stirred spinner flask to overcome the limitation of nutrient transport in conventional cell culture dish. This bioreactor culture facilitates cell proliferation and enlarges sizes of $\beta$-cell aggregates with enhanced responsibility to glucose level and incretin level [125] (Figure 3).

\section{Concluding remark}

Diabetes mellitus become global epidemic diseases in recent years. Especially T2D affects $5.9 \%$ of the world's adult population with limited medication and treatment. This necessitates seeking of novel treatments to control the increase rate of the diseases. Studies have revealed that multiple mitogens or cell-ECM or cell-cell communications can induce biologically functional $\beta$-cell proliferation through multitude nutrient and growth factors. Furthermore, understanding $\beta$-cell dysfunction and failure mechanism in the development of onset of diabetes is crucial to optimize the treatment options. Due to the extremely low proliferation capability and survival rate of the islet $\beta$-cells after isolation procedures, finding out new cell sources for production of clinically relevant $\beta$-cells is one of the topics in the field of tissue engineering and regenerative medicine for diabetic treatment. Currently, there are three types of cell sources in the field of regenerative medicine to produce $\beta$-cells. They are stem cells, endocrine progenitors, and other mature cells in the pancreas and $\beta$-cell itself [126]. Significant progresses have been achieved for each of these strategies. For example, at first glance, human embryonic stem cell (hESC) and its counterpart named induced pluripotent stem cell (iPSC) are considered to be promising sources for $\beta$-cell generation in vitro. Nevertheless, the differentiation procedure is still under development and investigation. Besides, the risk of teratoma formation in vitro remains a major concern if therapeutic $\beta$-cells are produced from hESCs or iPSCs. On the other hand, it is possible to produce $\beta$-cells from duct-lining, acinar cells [127], or hepatocytes [128], even though it is still under a controversial discussion [129]. It remains unclear which approach will prove ultimately to be successful in clinical applications. To date it remains to be a significant challenge to generate sufficient biologically functional $\beta$-cells to replace damaged or malfunctional $\beta$-cells. Most likely, the future of diabetes therapies rely on the combination of fabrication of novel constructor with integration of cell, signal molecule, and biomaterial that mimics microenvironment that is suitable for islet $\beta$-cell development in the body.

\section{Competing interest}

The authors declare that they have no competing interests.

\section{Authors' contributions}

HA drafted the manuscript. SJ revised and approved the manuscript. Both authors read and approved the final manuscript.

\section{Author details}

'Department of Bioengineering, College of Engineering, University of Arkansas, Fayetteville, AR 72701, USA. ²Department of Bioengineering, Thomas J. Watson School of Engineering and Applied Sciences, State University of New York in Binghamton, Binghamton, NY 13902, USA. ${ }^{3}$ College of Applied Medical Sciences, King Saud bin Abdulaziz University for Health Sciences, National Guard - Health Affairs, P.O. Box 2490, Riyadh 11426, Kingdom of Saudi Arabia. 
Received: 7 November 2013 Accepted: 29 January 2014

Published: 4 March 2014

\section{References}

1. Kloppel G, Lohr M, Habich K, Oberholzer M, Heitz PU: Islet pathology and the pathogenesis of type 1 and type 2 diabetes mellitus revisited. Surv Synth Pathol Res 1985, 4(2):110-125.

2. Centers for Disease Control and Prevention. National Diabetes Fact Sheet 2011. http://www.cdc.gov/diabetes/pubs/estimates11.htm

3. Alwan A: Global Status Report on Noncommunicable Diseases 2010. Geneva, Switzerland: World Health Organization; 2011.

4. Daneman D: Type 1 diabetes. Lancet 2006, 367(9513):847-858.

5. Shapiro AM, Lakey JR, Ryan EA, Korbutt GS, Toth E, Warnock GL, Kneteman NM, Rajotte RV: Islet transplantation in seven patients with type 1 diabetes mellitus using a glucocorticoid-free immunosuppressive regimen. $N$ Engl J Med 2000, 343(4):230-238.

6. Ribaux P, Ehses JA, Lin-Marq N, Carrozzino F, Boni-Schnetzler M, Hammar E, Irminger JC, Donath MY, Halban PA: Induction of CXCL1 by extracellular matrix and autocrine enhancement by interleukin-1 in rat pancreatic beta-cells. Endocrinology 2007, 148(11):5582-5590.

7. Buteau J, El-Assaad W, Rhodes CJ, Rosenberg L, Joly E, Prentki M: Glucagon-like peptide-1 prevents beta cell glucolipotoxicity. Diabetologia 2004, 47(5):806-815.

8. Nir T, Melton DA, Dor Y: Recovery from diabetes in mice by beta cell regeneration. J Clin Invest 2007, 117(9):2553-2561.

9. Rieck S, Kaestner KH: Expansion of beta-cell mass in response to pregnancy. Trends Endocrinol Metab 2010, 21(3):151-158.

10. de Gasparo M, Milner GR, Norris PD, Milner RD: Effect of glucose and amino acids on foetal rat pancreatic growth and insulin secretion in vitro. J Endocrinol 1978, 77(2):241-248.

11. Sjoholm A: Diabetes mellitus and impaired pancreatic beta-cell proliferation. J Intern Med 1996, 239(3):211-220.

12. Garofalo RS, Orena SJ, Rafidi K, Torchia AJ, Stock JL, Hildebrandt AL, Coskran T, Black SC, Brees DJ, Wicks JR, et al: Severe diabetes, age-dependent loss of adipose tissue, and mild growth deficiency in mice lacking Akt2/PKB beta. J Clin Invest 2003, 112(2):197-208.

13. Heit JJ, Karnik SK, Kim SK: Intrinsic regulators of pancreatic beta-cell proliferation. Annu Rev Cell Dev Biol 2006, 22:311-338.

14. Eberhard D, Lammert E: The pancreatic beta-cell in the islet and organ community. Curr Opin Genet Dev 2009, 19(5):469-475.

15. Nobukini T, Thomas G: The mTOR/S6K signalling pathway: the role of the TSC1/2 tumour suppressor complex and the proto-oncogene rheb. Novartis Found Symp 2004, 262:148-154. discussion 154-149, 265-148.

16. Wojtusciszyn A, Armanet M, Morel P, Berney T, Bosco D: Insulin secretion from human beta cells is heterogeneous and dependent on cell-to-cell contacts. Diabetologia 2008, 51(10):1843-1852.

17. Unger RH, Orci L: Paracrinology of islets and the paracrinopathy of diabetes. Proc Natl Acad Sci U S A 2010, 107(37):16009-16012.

18. Ahren B: Autonomic regulation of islet hormone secretion-implications for health and disease. Diabetologia 2000, 43(4):393-410.

19. Drucker DJ: The role of gut hormones in glucose homeostasis. J Clin Invest 2007, 117(1):24-32

20. Merani S, Shapiro AM: Current status of pancreatic islet transplantation. Clin Sci (Lond) 2006, 110(6):611-625.

21. Wang RN, Paraskevas S, Rosenberg L: Characterization of integrin expression in islets isolated from hamster, canine, porcine, and human pancreas. J Histochem Cytochem 1999, 47(4):499-506.

22. Swenne I: The role of glucose in the in vitro regulation of cell cycle kinetics and proliferation of fetal pancreatic B-cells. Diabetes 1982, 31(9):754-760.

23. Gahr S, Merger M, Bollheimer LC, Hammerschmied CG, Scholmerich J, Hug SR: Hepatocyte growth factor stimulates proliferation of pancreatic betacells particularly in the presence of subphysiological glucose concentrations. J Mol Endocrinol 2002, 28(2):99-110.

24. Hoorens A, Van de Casteele M, Kloppel G, Pipeleers D: Glucose promotes survival of rat pancreatic beta cells by activating synthesis of proteins which suppress a constitutive apoptotic program. J Clin Invest 1996, 98(7):1568-1574.

25. Tyrberg B, Eizirik DL, Hellerstrom C, Pipeleers DG, Andersson A: Human pancreatic beta-cell deoxyribonucleic acid-synthesis in islet grafts decreases with increasing organ donor age but increases in response to glucose stimulation in vitro. Endocrinology 1996, 137(12):5694-5699.
26. Alonso LC, Yokoe T, Zhang P, Scott DK, Kim SK, O'Donnell CP, Garcia-Ocana A: Glucose infusion in mice: a new model to induce beta-cell replication. Diabetes 2007, 56(7):1792-1801.

27. Bernard C, Berthault MF, Saulnier C, Ktorza A: Neogenesis vs. apoptosis as main components of pancreatic beta cell ass changes in glucose-infused normal and mildly diabetic adult rats. Faseb J 1999, 13(10):1195-1205.

28. Paris M, Bernard-Kargar C, Berthault MF, Bouwens L, Ktorza A: Specific and combined effects of insulin and glucose on functional pancreatic beta-cell mass in vivo in adult rats. Endocrinology 2003, 144(6):2717-2727.

29. Chang-Chen KJ, Mullur R, Bernal-Mizrachi E: Beta-cell failure as a complication of diabetes. Rev Endocr Metab Disord 2008, 9(4):329-343.

30. Ohsugi M, Cras-Meneur C, Zhou Y, Warren W, Bernal-Mizrachi E, Permutt MA: Glucose and insulin treatment of insulinoma cells results in transcriptional regulation of a common set of genes. Diabetes 2004, 53(6):1496-1508.

31. Vaulont $\mathrm{S}$, Vasseur-Cognet M, Kahn A: Glucose regulation of gene transcription. J Biol Chem 2000, 275(41):31555-31558.

32. Bernal-Mizrachi E, Wen W, Stahlhut S, Welling CM, Permutt MA: Islet beta cell expression of constitutively active Akt1/PKB alpha induces striking hypertrophy, hyperplasia, and hyperinsulinemia. J Clin Invest 2001, 108(11):1631-1638.

33. Tuttle RL, Gill NS, Pugh W, Lee JP, Koeberlein B, Furth EE, Polonsky KS, Naji A, Birnbaum MJ: Regulation of pancreatic beta-cell growth and survival by the serine/threonine protein kinase Akt1/PKBalpha. Nat Med 2001, 7(10):1133-1137.

34. Heit JJ, Apelqvist AA, Gu X, Winslow MM, Neilson JR, Crabtree GR, Kim SK: Calcineurin/NFAT signalling regulates pancreatic beta-cell growth and function. Nature 2006, 443(7109):345-349.

35. Bernal-Mizrachi E, Wice B, Inoue H, Permutt MA: Activation of serum response factor in the depolarization induction of Egr-1 transcription in pancreatic islet beta-cells. J Biol Chem 2000, 275(33):25681-25689.

36. Jhala US, Canettieri G, Screaton RA, Kulkarni RN, Krajewski S, Reed J, Walker $\mathrm{J}$, Lin X, White M, Montminy M: CAMP promotes pancreatic beta-cell survival via CREB-mediated induction of IRS2. Genes Dev 2003, 17(13):1575-1580.

37. Poitout V, Olson LK, Robertson RP: Chronic exposure of betaTC- 6 cells to supraphysiologic concentrations of glucose decreases binding of the RIPE3b1 insulin gene transcription activator. J Clin Invest 1996, 97(4):1041-1046.

38. Poitout V, Robertson RP: Minireview: secondary beta-cell failure in type 2 diabetes-a convergence of glucotoxicity and lipotoxicity. Endocrinology 2002, 143(2):339-342.

39. Lawrence MC, Bhatt HS, Watterson JM, Easom RA: Regulation of insulin gene transcription by a $\mathrm{Ca}(2+)$-responsive pathway involving calcineurin and nuclear factor of activated T cells. Mol Endocrinol 2001, 15(10):1758-1767.

40. Lawrence MC, Bhatt HS, Easom RA: NFAT regulates insulin gene promoter activity in response to synergistic pathways induced by glucose and glucagon-like peptide-1. Diabetes 2002, 51(3):691-698.

41. Sharma A, Olson LK, Robertson RP, Stein R: The reduction of insulin gene transcription in HIT-T15 beta cells chronically exposed to high glucose concentration is associated with the loss of RIPE3b1 and STF-1 transcription factor expression. Mol Endocrinol 1995, 9(9):1127-1134.

42. Harmon JS, Stein R, Robertson RP: Oxidative stress-mediated, posttranslational loss of MafA protein as a contributing mechanism to loss of insulin gene expression in glucotoxic beta cells. J Biol Chem 2005, 280(12):11107-11113.

43. da Silva XG, Leclerc I, Varadi A, Tsuboi T, Moule SK, Rutter GA: Role for AMP-activated protein kinase in glucose-stimulated insulin secretion and preproinsulin gene expression. Biochem J 2003, 371(Pt 3):761-774.

44. Nyblom HK, Sargsyan E, Bergsten P: AMP-activated protein kinase agonist dose dependently improves function and reduces apoptosis in glucotoxic beta-cells without changing triglyceride levels. J Mol Endocrinol 2008, 41(3):187-194.

45. Unger RH, Zhou YT, Orci L: Regulation of fatty acid homeostasis in cells: novel role of leptin. Proc Natl Acad Sci U S A 1999, 96(5):2327-2332.

46. Fridlyand LE, Philipson LH: Does the glucose-dependent insulin secretion mechanism itself cause oxidative stress in pancreatic beta-cells? Diabetes 2004, 53(8):1942-1948.

47. Nyblom HK, Thorn K, Ahmed M, Bergsten P: Mitochondrial protein patterns correlating with impaired insulin secretion from INS-1E cells exposed to elevated glucose concentrations. Proteomics 2006, 6(19):5193-5198. 
48. Robertson RP, Harmon JS: Diabetes, glucose toxicity, and oxidative stress: a case of double jeopardy for the pancreatic islet beta cell. Free Radic Biol Med 2006, 41(2):177-184

49. Kaneto H, Xu G, Fujii N, Kim S, Bonner-Weir S, Weir GC: Involvement of c-Jun N-terminal kinase in oxidative stress-mediated suppression of insulin gene expression. J Biol Chem 2002, 277(33):30010-30018.

50. Kawasaki E, Abiru N, Eguchi K: Prevention of type 1 diabetes: from the view point of beta cell damage. Diabetes Res Clin Pract 2004, 66(Suppl 1):S27-S32.

51. Aguirre V, Uchida T, Yenush L, Davis R, White MF: The c-Jun NH(2)-terminal kinase promotes insulin resistance during association with insulin receptor substrate-1 and phosphorylation of Ser(307). J Biol Chem 2000, 275(12):9047-9054

52. Gunton JE, Kulkarni RN, Yim S, Okada T, Hawthorne WJ, Tseng YH, Roberson RS, Ricordi C, O'Connell PJ, Gonzalez FJ, et al: Loss of ARNT/HIF1beta mediates altered gene expression and pancreatic-islet dysfunction in human type 2 diabetes. Cell 2005, 122(3):337-349.

53. Cantley J, Selman C, Shukla D, Abramov AY, Forstreuter F, Esteban MA Claret M, Lingard SJ, Clements M, Harten SK, et al: Deletion of the von Hippel-Lindau gene in pancreatic beta cells impairs glucose homeostasis in mice. J Clin Invest 2009, 119(1):125-135.

54. Puri S, Cano DA, Hebrok M: A role for von Hippel-Lindau protein in pancreatic beta-cell function. Diabetes 2009, 58(2):433-441.

55. Grill V, Bjorklund A: Overstimulation and beta-cell function. Diabetes 2001, 50(Suppl 1):S122-S124

56. Maedler K, Sergeev P, Ris F, Oberholzer J, Joller-Jemelka HI, Spinas GA, Kaiser N, Halban PA, Donath MY: Glucose-induced beta cell production of IL-1 beta contributes to glucotoxicity in human pancreatic islets. J Clin Invest 2002, 110(6):851-860.

57. Kulkarni RN: New insights into the roles of insulin/IGF-I in the development and maintenance of beta-cell mass. Rev Endocr Metab Disord 2005, 6(3):199-210.

58. Hogg J, Han VK, Clemmons DR, Hill DJ: Interactions of nutrients, insulin-like growth factors (IGFs) and IGF-binding proteins in the regulation of DNA synthesis by isolated fetal rat islets of Langerhans. J Endocrinol 1993, 138(3):401-412.

59. George M, Ayuso E, Casellas A, Costa C, Devedjian JC, Bosch F: Beta cell expression of IGF-I leads to recovery from type 1 diabetes. $J$ Clin Invest 2002, 109(9):1153-1163.

60. Petrik J, Pell JM, Arany E, McDonald TJ, Dean WL, Reik W, Hill DJ: Overexpression of insulin-like growth factor-II in transgenic mice is associated with pancreatic islet cell hyperplasia. Endocrinology 1999, 140(5):2353-2363.

61. Kulkarni RN, Bruning JC, Winnay JN, Postic C, Magnuson MA, Kahn CR: Tissue-specific knockout of the insulin receptor in pancreatic beta cells creates an insulin secretory defect similar to that in type 2 diabetes. Cell 1999, 96(3):329-339.

62. Saltiel $A R$, Kahn CR: Insulin signalling and the regulation of glucose and lipid metabolism. Nature 2001, 414(6865):799-806

63. Ohsugi M, Cras-Meneur C, Zhou Y, Bernal-Mizrachi E, Johnson JD, Luciani DS, Polonsky KS, Permutt MA: Reduced expression of the insulin receptor in mouse insulinoma (MIN6) cells reveals multiple roles of insulin signaling in gene expression, proliferation, insulin content, and secretion. J Bio/ Chem 2005, 280(6):4992-5003

64. Bruning JC, Winnay J, Bonner-Weir S, Taylor SI, Accili D, Kahn CR: Development of a novel polygenic model of NIDDM in mice heterozygous for IR and IRS-1 null alleles. Cell 1997, 88(4):561-572.

65. Withers DJ, Gutierrez JS, Towery H, Burks DJ, Ren JM, Previs S, Zhang Y, Bernal D, Pons S, Shulman Gl, et al: Disruption of IRS-2 causes type 2 diabetes in mice. Nature 1998, 391(6670):900-904

66. Lingohr MK, Dickson LM, McCuaig JF, Hugl SR, Twardzik DR, Rhodes CJ: Activation of IRS-2-mediated signal transduction by IGF-1, but not TGF-alpha or EGF, augments pancreatic beta-cell proliferation. Diabetes 2002, 51(4):966-976

67. Fan $\mathrm{R}$, Li X, Gu X, Chan JC, Xu G: Exendin-4 protects pancreatic beta cells from human islet amyloid polypeptide-induced cell damage: potential involvement of AKT and mitochondria biogenesis. Diabetes Obes Metab 2010, 12(9):815-824.

68. Park S, Dong X, Fisher TL, Dunn S, Omer AK, Weir G, White MF: Exendin-4 uses Irs2 signaling to mediate pancreatic beta cell growth and function. J Biol Chem 2006, 281(2):1159-1168.
69. Kaiser G, Gerst F, Michael D, Berchtold S, Friedrich B, Strutz-Seebohm N, Lang F, Haring HU, Ullrich S: Regulation of forkhead box 01 (FOXO1) by protein kinase $B$ and glucocorticoids: different mechanisms of induction of beta cell death in vitro. Diabetologia 2013, 56(7):1587-1595.

70. Nakae J, Biggs WH 3rd, Kitamura T, Cavenee WK, Wright CV, Arden KC, Accili D: Regulation of insulin action and pancreatic beta-cell function by mutated alleles of the gene encoding forkhead transcription factor Foxo1. Nat Genet 2002, 32(2):245-253.

71. Tanabe K, Liu Z, Patel S, Doble BW, Li L, Cras-Meneur C, Martinez SC, Welling CM, White MF, Bernal-Mizrachi E, et al: Genetic deficiency of glycogen synthase kinase-3beta corrects diabetes in mouse models of insulin resistance. PLOS Biol 2008, 6(2):e37.

72. McKinnon CM, Docherty K: Pancreatic duodenal homeobox-1, PDX-1, a major regulator of beta cell identity and function. Diabetologia 2001, 44(10):1203-1214.

73. Kushner JA, Ye J, Schubert M, Burks DJ, Dow MA, Flint CL, Dutta S, Wright CV, Montminy MR, White MF: Pdx1 restores beta cell function in Irs2 knockout mice. J Clin Invest 2002, 109(9):1193-1201.

74. Kitamura T, Nakae J, Kitamura Y, Kido Y, Biggs WH 3rd, Wright CV, White MF, Arden KC, Accili D: The forkhead transcription factor Foxo1 links insulin signaling to Pdx1 regulation of pancreatic beta cell growth. J Clin Invest 2002, 110(12):1839-1847.

75. Kobayashi M, Kikuchi O, Sasaki T, Kim HJ, Yokota-Hashimoto H, Lee YS, Amano K, Kitazumi T, Susanti VY, Kitamura Yl, et al: FoxO1 as a double-edged sword in the pancreas: analysis of pancreas- and beta-cell-specific FoxO1 knockout mice. Am J Physiol Endocrinol Metab 2012, 302(5):E603-E613.

76. Kawamori D, Kaneto H, Nakatani Y, Matsuoka TA, Matsuhisa M, Hori M, Yamasaki Y: The forkhead transcription factor Foxo1 bridges the JNK pathway and the transcription factor PDX-1 through its intracellular translocation. J Biol Chem 2006, 281(2):1091-1098.

77. Vasavada RC, Garcia-Ocana A, Zawalich WS, Sorenson RL, Dann P, Syed M, Ogren L, Talamantes F, Stewart AF: Targeted expression of placental lactogen in the beta cells of transgenic mice results in beta cell proliferation, islet mass augmentation, and hypoglycemia. J Biol Chem 2000, 275(20):15399-15406.

78. Parsons JA, Brelje TC, Sorenson RL: Adaptation of islets of Langerhans to pregnancy: increased islet cell proliferation and insulin secretion correlates with the onset of placental lactogen secretion. Endocrinology 1992, 130(3):1459-1466.

79. Freemark M, Avril I, Fleenor D, Driscoll P, Petro A, Opara E, Kendall W, Oden J, Bridges S, Binart N, et al: Targeted deletion of the PRL receptor: effects on islet development, insulin production, and glucose tolerance. Endocrinology 2002, 143(4):1378-1385.

80. Nielsen JH, Galsgaard ED, Moldrup A, Friedrichsen BN, Billestrup N, Hansen JA, Lee YC, Carlsson C: Regulation of beta-cell mass by hormones and growth factors. Diabetes 2001, 50(Suppl 1):S25-S29.

81. Matsumoto K, Nakamura T: Emerging multipotent aspects of hepatocyte growth factor. J Biochem 1996, 119(4):591-600.

82. Dai C, Li Y, Yang J, Liu Y: Hepatocyte growth factor preserves beta cell mass and mitigates hyperglycemia in streptozotocin-induced diabetic mice. J Biol Chem 2003, 278(29):27080-27087.

83. Garcia-Ocana A, Vasavada RC, Cebrian A, Reddy V, Takane KK, Lopez-Talavera JC, Stewart AF: Transgenic overexpression of hepatocyte growth factor in the beta-cell markedly improves islet function and islet transplant outcomes in mice. Diabetes 2001, 50(12):2752-2762.

84. Rane SG, Lee JH, Lin HM: Transforming growth factor-beta pathway: role in pancreas development and pancreatic disease. Cytokine Growth Factor Rev 2006, 17(1-2):107-119.

85. Anderson MS, Bluestone JA: The NOD mouse: a model of immune dysregulation. Annu Rev Immunol 2005, 23:447-485.

86. Suarez-Pinzon WL, Marcoux Y, Ghahary A, Rabinovitch A: Gene transfection and expression of transforming growth factor-beta1 in nonobese diabetic mouse islets protects beta-cells in syngeneic islet grafts from autoimmune destruction. Cell Transplant 2002, 11(6):519-528.

87. Lin HM, Lee JH, Yadav H, Kamaraju AK, Liu E, Zhigang D, Vieira A, Kim SJ, Collins $\mathrm{H}$, Matschinsky F, et al: Transforming growth factor-beta/Smad3 signaling regulates insulin gene transcription and pancreatic islet beta-cell function. J Biol Chem 2009, 284(18):12246-12257.

88. Shalev A, Pise-Masison CA, Radonovich M, Hoffmann SC, Hirshberg B, Brady JN, Harlan DM: Oligonucleotide microarray analysis of intact human pancreatic 
islets: identification of glucose-responsive genes and a highly regulated TGFbeta signaling pathway. Endocrinology 2002, 143(9):3695-3698.

89. Drucker DJ: The biology of incretin hormones. Cell Metab 2006, 3(3):153-165.

90. Farilla L, Bulotta A, Hirshberg B, Li Calzi S, Khoury N, Noushmehr H, Bertolotto C, Di Mario U, Harlan DM, Perfetti R: Glucagon-like peptide 1 inhibits cell apoptosis and improves glucose responsiveness of freshly isolated human islets. Endocrinology 2003, 144(12):5149-5158.

91. Issa CM, Azar ST: Possible role of GLP-1 and its agonists in the treatment of type 1 diabetes mellitus. Curr Diab Rep 2012, 12(5):560-567.

92. Trumper A, Trumper K, Trusheim H, Arnold R, Goke B, Horsch D: Glucosedependent insulinotropic polypeptide is a growth factor for beta (INS-1) cells by pleiotropic signaling. Mol Endocrinol 2001, 15(9):1559-1570.

93. Christensen M, Vedtofte L, Holst JJ, Vilsboll T, Knop FK: Glucose-dependent insulinotropic polypeptide: a bifunctional glucose-dependent regulator of glucagon and insulin secretion in humans. Diabetes 2011, 60(12):3103-3109.

94. Holz GG, Leech CA, Heller RS, Castonguay M, Habener JF: cAMP-dependent mobilization of intracellular $\mathrm{Ca} 2+$ stores by activation of ryanodine receptors in pancreatic beta-cells. A Ca2+ signaling system stimulated by the insulinotropic hormone glucagon-like peptide-1-(7-37). J Biol Chem 1999, 274(20):14147-14156.

95. Tsuboi T, da Silva XG, Holz GG, Jouaville LS, Thomas AP, Rutter GA Glucagon-like peptide-1 mobilizes intracellular $\mathrm{Ca} 2+$ and stimulates mitochondrial ATP synthesis in pancreatic MIN6 beta-cells. Biochem J 2003, 369(Pt 2):287-299.

96. Wang RN, Rosenberg L: Maintenance of beta-cell function and survival following islet isolation requires re-establishment of the islet-matrix relationship. J Endocrinol 1999, 163(2):181-190.

97. Li Y, Cao X, Li LX, Brubaker PL, Edlund H, Drucker DJ: beta-Cell Pdx1 expression is essential for the glucoregulatory, proliferative, and cytoprotective actions of glucagon-like peptide-1. Diabetes 2005, 54(2):482-491.

98. Buteau J, Foisy S, Joly E, Prentki M: Glucagon-like peptide 1 induces pancreatic beta-cell proliferation via transactivation of the epidermal growth factor receptor. Diabetes 2003, 52(1):124-132.

99. Shao W, Wang Z, Ip W, Chiang YT, Xiong X, Chai T, Xu C, Wang Q, Jin T: GLP-1 (28-36) improves beta-cell mass and glucose disposal in streptozotocin induced diabetes mice and activates PKA-beta-catenin signaling in beta-cells in vitro. Am J Physiol Endocrinol Metab 2013, 304(12):E1263-1272

100. Nagata NA, Inoue K, Tabata Y: Co-culture of extracellular matrix suppresses the cell death of rat pancreatic islets. J Biomater Sci Polym Ed 2002, 13(5):579-590.

101. Beattie GM, Rubin JS, Mally MI, Otonkoski T, Hayek A: Regulation of proliferation and differentiation of human fetal pancreatic islet cells by extracellular matrix, hepatocyte growth factor, and cell-cell contact. Diabetes 1996, 45(9):1223-1228

102. Kaido T, Yebra M, Cirulli V, Rhodes C, Diaferia G, Montgomery AM: Impact of defined matrix interactions on insulin production by cultured human beta-cells: effect on insulin content, secretion, and gene transcription. Diabetes 2006, 55(10):2723-2729.

103. Rutti S, Sauter NS, Bouzakri K, Prazak R, Halban PA, Donath MY: In vitro proliferation of adult human beta-cells. PLoS One 2012, 7(4):e35801.

104. Parnaud G, Bosco D, Berney T, Pattou F, Kerr-Conte J, Donath MY, Bruun C, Mandrup-Poulsen T, Billestrup N, Halban PA: Proliferation of sorted human and rat beta cells. Diabetologia 2008, 51(1):91-100.

105. Juliano RL, Haskill S: Signal transduction from the extracellular matrix. J Cell Biol 1993, 120(3):577-585.

106. Bosco D, Meda P, Halban PA, Rouiller DG: Importance of cell-matrix interactions in rat islet beta-cell secretion in vitro: role of alpha6beta1 integrin. Diabetes 2000, 49(2):233-243.

107. Krishnamurthy M, Li J, Al-Masri M, Wang R: Expression and function of alphabeta1 integrins in pancretic beta (INS-1) cells. J Cell Commun Signal 2008, 2(3-4):67-79.

108. Pinkse GG, Bouwman WP, Jiawan-Lalai R, Terpstra OT, Bruijn JA, de Heer E: Integrin signaling via RGD peptides and anti-beta1 antibodies confers resistance to apoptosis in islets of Langerhans. Diabetes 2006, 55(2):312-317.

109. Nikolova G, Jabs N, Konstantinova I, Domogatskaya A, Tryggvason K, Sorokin L, Fassler R, Gu G, Gerber HP, Ferrara N, et al: The vascular basement membrane: a niche for insulin gene expression and Beta cell proliferation. Dev Cell 2006, 10(3):397-405.
110. Lin CC, Anseth KS: Cell-cell communication mimicry with poly(ethylene glycol) hydrogels for enhancing beta-cell function. Proc Natl Acad Sci U S A 2011, 108(16):6380-6385.

111. Weber $L M$, Cheung CY, Anseth KS: Multifunctional pancreatic islet encapsulation barriers achieved via multilayer PEG hydrogels. Cell Transplant 2008, 16(10):1049-1057.

112. Weber LM, Hayda KN, Haskins K, Anseth KS: The effects of cell-matrix interactions on encapsulated beta-cell function within hydrogels functionalized with matrix-derived adhesive peptides. Biomaterials 2007, 28(19):3004-3011.

113. Bernard AB, Lin CC, Anseth KS: A microwell cell culture platform for the aggregation of pancreatic beta-cells. Tissue Eng Part C Methods 2012, 18(8):583-592

114. Kelly C, Parke HG, McCluskey JT, Flatt PR, McClenaghan NH: The role of glucagon- and somatostatin-secreting cells in the regulation of insulin release and beta-cell function in heterotypic pseudoislets. Diabetes Metab Res Rev 2010, 26(7):525-533.

115. Weber LM, Hayda KN, Anseth KS: Cell-matrix interactions improve beta-cell survival and insulin secretion in three-dimensional culture. Tissue Eng Part A 2008, 14(12):1959-1968.

116. Hiscox AM, Stone AL, Limesand S, Hoying JB, Williams SK: An isletstabilizing implant constructed using a preformed vasculature. Tissue Eng Part A 2008, 14(3):433-440.

117. Su J, Hu BH, Lowe WL Jr, Kaufman DB, Messersmith PB: Anti-inflammatory peptide-functionalized hydrogels for insulin-secreting cell encapsulation. Biomaterials 2010, 31(2):308-314.

118. Wang JL, Qian X, Chinookoswong N, Lu J, Chow G, Theill LE, Shi ZQ: Polyethylene glycolated recombinant TNF receptor I improves insulitis and reduces incidence of spontaneous and cyclophosphamide-accelerated diabetes in nonobese diabetic mice. Endocrinology 2002, 143(9):3490-3497.

119. Skiles ML, Wilder NB, Sahai S, Blanchette JO: Identifying HIF activity in three-dimensional cultures of islet-like clusters. Int J Artif Organs 2013, 36(3):175-183.

120. Pedraza E, Coronel MM, Fraker CA, Ricordi C, Stabler CL: Preventing hypoxia-induced cell death in beta cells and islets via hydrolytically activated, oxygen-generating biomaterials. Proc Natl Acad Sci U S A 2012, 109(11):4245-4250

121. Fraker CA, Alvarez S, Papadopoulos P, Giraldo J, Gu W, Ricordi C, Inverardi L, Dominguez-Bendala J: Enhanced oxygenation promotes beta-cell differentiation in vitro. Stem Cells 2007, 25(12):3155-3164.

122. Sato $Y$, Endo $H$, Okuyama $H$, Takeda $T$, Iwahashi $H$, Imagawa A, Yamagata $K$, Shimomura I, Inoue M: Cellular hypoxia of pancreatic beta-cells due to high levels of oxygen consumption for insulin secretion in vitro. $J$ Bio Chem 2011, 286(14):12524-12532.

123. Cantley J, Grey ST, Maxwell PH, Withers DJ: The hypoxia response pathway and beta-cell function. Diabetes Obes Metab 2010, 12(Suppl 2):159-167.

124. Wu H, Avgoustiniatos ES, Swette L, Bonner-Weir S, Weir GC, Colton CK: In situ electrochemical oxygen generation with an immunoisolation device. Ann N Y Acad Sci 1999, 875:105-125.

125. Lock LT, Laychock SG, Tzanakakis ES: Pseudoislets in stirred-suspension culture exhibit enhanced cell survival, propagation and insulin secretion. J Biotechnol 2011, 151(3):278-286

126. Borowiak M, Melton DA: How to make beta cells? Curr Opin Cell Biol 2009, 21(6):727-732

127. Bonner-Weir S, Weir GC: New sources of pancreatic beta-cells. Nat Biotechnol 2005, 23(7):857-861.

128. Porat S, Dor Y: New sources of pancreatic beta cells. Curr Diab Rep 2007. 7(4):304-308.

129. Kushner JA, Weir GC, Bonner-Weir S: Ductal origin hypothesis of pancreatic regeneration under attack. Cell Metab 2010, 11(1):2-3.

doi:10.1186/2045-3701-4-12

Cite this article as: Alismail and Jin: Microenvironmental stimuli for

proliferation of functional islet $\beta$-cells. Cell \& Bioscience 2014 4:12. 